IWONA BURKACKA

Uniwersytet Warszawski

Instytut Języka Polskiego

\title{
Dlaczego spopielarnia, a nie krematorium \\ O innowacjach alternatywnych inaczej
}

Słowa klucze: innowacja, zapożyczenie, neosemantyzm, neologizm słowotwórczy, funkcja perswazyjna

Innowacje alternatywne zwykle nie zyskują aprobaty normatywistów, w przeciwieństwie do uzupełniających i skracających, których ocena jest z reguły pozytywna. Neologizmy nominatywne bowiem nazywają realia (zjawiska, procesy, rzeczy, zawody itp.) nowe lub ,postrzegane jako nowe, a dotąd nienazwane" (Markowski 2005: 50), a ekspresywizmy w nowy sposób opisują to, co jest już nazwane, są wyrazem stosunku mówiącego do opisywanego zjawiska, rzeczy czy osoby. Sam ładunek emocjonalny nie musi być nowy, nowa jest forma jego wyrażenia, co jest istotne, ponieważ z czasem słowa tracą swoją ekspresywność, ,wycierają się”. Ze względu na zaspokajanie istniejących potrzeb nazewniczych czy ekspresywnych obie te grupy innowacji uzupełniających zyskują aprobatę normatywną ${ }^{1}$.

Innowacje skracające powstają zaś w wyniku działania tendencji do skrótu, są wyrazem dążenia do ekonomiczności, minimalizowania wysiłku mówiącego, a niekiedy swoistego etykietyzowania, które polega na sprowadze-

1 „Poprawne są takie nowe wyrazy, połączenia wyrazowe itp., które uzupełniają zasób środków językowych poprzez wprowadzenie elementów nazywających (nominatywnych) lub ekspresywnych" (Markowski 2005: 49). 
niu opisu zjawiska, postawy, osoby do krótkiej, zwykle jednowyrazowej formy, np. machosystem 'system z dominującą pozycją mężczyzn' (dziś wyraz zwykle używany w kontekście roli kobiet we Włoszech). Neologizmy tego typu mogą być postrzegane jako neutralne stylistycznie (uzdatnialnia 'stacja uzdatniania wody') lub nacechowane, właściwe odmianom środowiskowym polszczyzny, np. paź 'październik' (w gwarze uczniowskiej). Często ich występowanie jest charakterystyczne dla niektórych odmian polszczyzny i w ich granicach aprobowane.

Warto dodać, że granica między innowacjami uzupełniającymi a skracającymi jest nieostra. Można bowiem rozpatrywać przywołane wyżej przykłady (machosystem, uzdatnialnia, paź) jako pewien podtyp neologizmów nominatywnych czy ekspresywnych. Co prawda, desygnaty istnieją od dawna i mają swoje nazwy, ale nowe słowa albo niosą nacechowanie (np. paź to nie jest neutralna nazwa miesiąca, lecz nacechowana stylistycznie), albo kondensują treść nazwy wielowyrazowej (dwa pozostałe przykłady). Często zaś nacechowanie ekspresywne czy stylistyczne jest związane ze skrótowością i nowością neologizmów, ponieważ ich wartość ekspresywna wynika z nowego ujmowania zjawisk mających już nazwy. Następuje proces reinterpretacji semantycznej (Grabias 1981: 95).

Inaczej wygląda ocena innowacji alternatywnych. Zdaniem A. Markowskiego innowacje te ,pojawiają się obok wyrazów, form i połączeń już istniejących, jako wynik nasilania się nowych tendencji językowych", np. mody na zapożyczenia angielskie (Markowski 2005: 43), i dublują nazwy już funkcjonujące w polszczyźnie, stąd - jego zdaniem - nie widać uzasadnienia dla ich istnienia. Aprobaty nie zyskują więc słowa: *shop, *tabloid, *akcesja (Markowski 2005: 50).

Powstaje jednak pytanie, czy rzeczywiście innowacje alternatywne jedynie dublują, powielają znaczenia. Może warto przyjrzeć się kilku przykładom, które ani nie nazywają nowych zjawisk, ani nie są typowymi ekspresywnymi odpowiednikami istniejących nazw, a często nie zmniejszają również wysiłku nadawcy tekstu, i odpowiedzieć na pytanie, po co powołano je do życia.

Spójrzmy na kilka przykładów.

Zacznijmy od tytułowego słowa spopielarnia. Ten neologizm słowotwórczy występuje w wielu tekstach prasowych i internetowych oraz audycjach radiowych jako odpowiednik wyrazu krematorium. Jakie czynniki zadecydowały o tym, że jego frekwencja w niektórych typach tekstów jest znacz- 
na (w dziennikach, zwłaszcza w latach 2005-2006, dane na podstawie profilu diachronicznego wygenerowanego przez wyszukiwarkę PELCRA NKJP; dostęp: 20.05.2011), a sama innowacja zaczyna w publicystyce wypierać wyraz krematorium, który funkcjonuje w polszczyźnie od dość dawna.

Po pierwsze, dzieje się tak za sprawą podstawy słowotwórczej: czasownika spopielać i związków z rzeczownikiem popioły, oznaczającym ,szczątki pozostałe po spaleniu zwłok; prochy ludzkie, spalone zwłoki” (USJP) oraz wyrazem popiół 1. 'szary proszek pozostający po spaleniu substancji pochodzenia organicznego', 2. książk. przen. 'o czymś, co przestało istnieć, skończyło się' (USJP).

I choć hasło krematorium w pierwszym znaczeniu i wyrazy z nim słowotwórczo powiązane: kremacja, kremować II są opatrzone kwalifikatorem ksiażkowe, podobnie jak słowa spopielić, spopielać, spopielały, spopieleć, spopielić się, spopielać się, popiót 2., popielisko, popielnica 1. 'duża popielniczka', to jednak gniazdo leksemu popiół zawiera też wyrazy o nacechowaniu poetyckim, podniosłym: popielić I, popielić się, oraz słowa o znaczeniu przenośnym: popiół 2. ksiażk. przen. i archeologicznym: popielnica 2. 'naczynie grobowe służące do przechowywania prochów zmarłego; urna', popielnicowy. Derywat spopielarnia dziedziczy więc ową książkowość, wzmacnianą odniesieniami do wyrazów podniosłych i poetyckich. Słowotwórczo jest przejrzysty, wykorzystano w nim bowiem typowy sufiks -arni$(a)^{2}$, budujący odczasownikowe nazwy miejsc, i rodzimy czasownik, będący częścią 34-elementowego gniazda leksemu POPIÓŁ 1., którego wielkość może świadczyć o głębokim zakorzenieniu w systemie leksykalnym polszczyzny i wypełnianiu istotnych potrzeb nazewniczych.

Po drugie, łączliwość wyrazów zawierających rdzeń popiót jest znacznie bogatsza niż łączliwość genetycznie obcego wyrazu krematorium i umacnia pozytywne skojarzenia: używając leksemów: popiót, popioły, spopielić, mówimy w sposób podniosły o suszy, pożarach, zniszczeniu, końcu życia, szczątkach zmarłych:

- pożar spopielit zagrodę, stońce spopieliło ziemię,

- spopielate zgliszcza, spopielate trawy,

- spopielona trawa, spopielone szczatki zabudowań,

- barwa popiotu,

${ }^{2}$ O nowszych derywatach z formantem -arni(a) - p. Burkacka 2010, Waszakowa 2007. 
- zamieniać w popiót,

- nadzieje, plany rozsypaty się w popiót,

- odgrzebać, wskrzesić przeszłość z popiołów,

- przysięgać na popioły swoich przodków [na podstawie USJP].

Większość frazeologizmów ${ }^{3}$ wzmacnia wzniosłość:

- ani dymu, ani popiołu,

- obrócić coś w popiót,

- posypać (sobie) gtowe popiołem,

- powstać, odrodzić sie jak Feniks z popiołów,

- spalić na popiót,

- rozsypać popioty na cztery strony świata [na podstawie [USJP].

Przywoływane są także skojarzenia mitologiczne (mity greckie: Feniks), biblijne (posypywanie głowy popiołem ${ }^{4}$ ), religijne (Popielec), literackie (C. Norwid, Tyrtej, prolog 3., J. Andrzejewski, Popiót i diament).

W celach perswazyjnych zatem przydatniejsze jest stosowanie formacji rodzimej niż jednostki genetycznie obcej.

Po trzecie, krematoria kojarzą się z II wojną światową i obozami koncentracyjnymi (to drugie znaczenie tego słowa odnotowane w USJP: 2. hist. 'w czasie II wojny światowej, w obozach hitlerowskich - miejsce spalania zwłok ofiar masowej zagłady'5). Przywołajmy typowe konteksty: krematoryjne piece, kominy; poddawać zwłoki kremacji; kremacja ciała; zakład kremacyjny, które w części wywołują negatywne skojarzenia, niepożądane, gdy chce się nakłonić ludzi do spopielania ciał zmarłych bliskich oraz wyrażenia zgody na budowę krematoriów, zwłaszcza w sąsiedztwie ich zamieszkania (a to są częste konteksty ${ }^{6}$ występowania słowa spopielarnia), np.

3 Poza jednym: nie zasypiać gruszek w popiele.

${ }^{4}$ Ks. Estery, 4,1; zwyczaj występujący również na Bliskim Wschodzie.

5 Interesujące jest wykorzystanie odmiennych słów w definicji pierwszego i drugiego znaczenia wyrazu krematorium: spopielanie i spalanie - 1. ksiażk. 'budynek wyposażony w specjalne piece do spopielania zwłok ludzkich', 2. hist. 'w czasie II wojny światowej, w obozach hitlerowskich - miejsce spalania zwłok ofiar masowej zagłady’ [wg USJP, podkreślenie: I.B.].

${ }^{6}$ Wszystkie cytaty z tekstów elektronicznych z dostępu 24.05.2011 r.; chyba że podano inaczej. 
(1) [...] na tarnobrzeskim osiedlu Sobów, ma być uruchomiona spopielarnia zwłok (www.radio.rzeszow.pl);

(2) W Dzień Zaduszny zakład udostępnił pomieszczenia spopielarni zainteresowanym (www.fakty.interia.pl);

(3) Kraków będzie miat wreszcie spopielarnię zwłok (www.gazetakrakowska.pl);

(4) Długo toczyła się w Krakowie dyskusja nad miejscem budowy spopielarni zwłok (www.kraker.pl);

(5) KREMATORIUM współczesna spopielarnia zwłok (www.tanatopraksja.mojeforum.net);

(6) W Łodzi rusza pierwsza $w$ świecie kościelna spopielarnia zwłok (www.wiadomosci24.pl);

(7) W Łodzi otwiera drzwi druga spopielarnia ciał. Łódź jest jedynym miastem $w$ Europie, $w$ którym sq aż dwa krematoria (www.lodz.naszemiasto.pl).

Po czwarte, całopalenie jako zwyczaj pogański było dawniej odrzucane w krajach chrześcijańskich, o czym pisała Anna Jasik (2009: 187), co nie pozostało bez wpływu na zwyczaj grzebania zmarłych. Na marginesie warto dodać, że w prasie, także katolickiej, w ostatnich latach zamieszczono kilka tekstów o kremacji zwłok katolików, pogrzebach i prawnych aspektach przechowywania urn?

Można więc rozpatrywać powołanie nowego słowa jako przejaw eufemizacji, omijania wyrazu objętego społecznym tabu ${ }^{8}$, rozumianym jako „to, co zakazane w ogóle, zakazane z jakiegokolwiek powodu" (Dąbrowska 1993: 19). Wyraz spopielarnia ma cechy, które uważa się za charakterystyczne dla eufemizmu: jest „komplementem dla desygnatu”, „kamufluje nazwę podstawo-

7 Edyta Mętel, Zanim zmartwychwstaniemy, „Tygodnik Powszechny” (www.tygodnik.com.pl/ numer/27113.metel); Igor Miecik, Zmarli przepędzajq żywych, „Polityka", nr 31 (2309), 4.08.201, s. 75-77; ks. Krzysztof Graczyk, Czy kremacja zwłok jest niezgodna $z$ wiarq chrześcijańska? (1), http://www.niedziela.pl/artykul_w_niedzieli.php?doc $=$ ed200330\&nr=204, edycja włocławska, 30/2003 [dostęp: 19.10.2011]; Irena Świerdzewska, Pogrzeb bez stypy, http://www.niedziela.pl/artykul_w_niedzieli.php?do$\mathrm{c}=\mathrm{ed} 200446 \& n r=148$, edycja warszawska, 46/2004 [dostęp: 19.10.2011].

8 Stanisław Widłak przyjmuje, że ,w językach nowożytnych tabu jest zakazem zabraniającym używania słów niepomyślnych, w jakimkolwiek znaczeniu szkodliwych, przykrych, niepoprawnych lub niepożądanych, eufemizm zaś oznacza zbiór sposobów językowych, przy których pomocy przebiera się i łagodzi koncept objęty tabu” (Widłak 1963: 102). 
wą", jest oryginalne, nowe i cechuje się świeżością skojarzeń. Ma pożądane nacechowanie: podniosłe, książkowe, uroczyste (Dąbrowska 1993: 44-45, 56 za Engelking 1984), i wzbudza pozytywne konotacje (Dąbrowska 1993: 56).

Wiarę w kreacyjną moc słowa widać też w coraz częstszym posługiwaniu się zapożyczeniem singiel ${ }^{9}$ i utworzonym od niego derywatem singielka. Ich tradycyjne odpowiedniki: osoba samotna, osoba niezamężna / nieżonata / stanu wolnego ${ }^{10}$, również stara panna, stary kawaler, niosą bowiem dodatkowe treści i konotacje, które są oceniane jako stygmatyzujące, niesprawiedliwe, kulturowo obciążone, narzucające negatywny obraz osoby. Sprzyja temu budowa z partykułą nie (niezamężna, nieżonaty), uwypuklającą niedostatki, braki, oraz łączliwość i frazeologia: starokawalerskie nałogi, nawyki, przywary, przyzwyczajenia ${ }^{11}$, staropanieńskie fochy, zwyczaje ${ }^{12}$, nudzić jak stara

9 Wyraz spotykany był w trzech wariantach ortograficznych: singel, singiel, syngiel (oddających różny stopień spolszczenia). Współcześnie jednak wyraz w znaczeniu 'osoba' ma ujednoliconą pisownię (singiel - por. Słownik ortograficzny PWN, www.pwn.pl), w przeciwieństwie do znaczenia 'płyta' pisanego na trzy sposoby. Wyraz singiel w znaczeniu osobowym opisuję jako zapożyczenie semantyczne, ponieważ między znaczeniami dotychczasowymi: 1. muz. 'płyta z nagraniem jednej melodii, jednego utworu muzycznego na każdej stronie', 2. sport. 'w tenisie, ping-pongu, badmintonie: rozgrywka między dwoma graczami; gra pojedyncza', 3. karc. 'jedyna karta w danym kolorze otrzymana przy rozdaniu; singleton' [wg USJP] a nowym daje się wykryć więź semantyczna (por. Waszakowa 2009: 211-214). Wspólnym elementem znaczeniowym jest pojedynczość.

${ }^{10}$ To sformułowanie częściej jest stosowane przez osoby rozwiedzione.

11 Według PSWP także: poglądy, hobby, zajęcie.

12 Według PSWP także: przywary, nawyki, przyzwyczajenia, wady, zachcianka. Typowe połączenia $\mathrm{z}$ rzeczownikiem staropanieństwo, wymienione $\mathrm{w}$ tym słowniku, wskazują na to, że jest to stan niepożądany: lęk przed staropanieństwem, wyśmiewać staropanieństwo, komuś grozi staropanieństwo (łączliwość rzeczownika starokawalerstwo nie pozwala na tak jednoznaczną ocenę: kultywować starokawalerstwo, wytrwać w starokawalerstwie, komuś grozi starokawalerstwo, żegnać się ze starokawalerstwem). Na tę asymetrię wskazują również Małgorzata Karwatowska i Jolanta Szpyra-Kozłowska. Ich zdaniem stary kawaler, ,jest widziany jako nieszkodliwy, nieco komiczny dziwak, któremu nie przypisuje się jednak złośliwości czy frustracji życiowej”, podczas gdy „stare panny są złośliwe i kłótliwe, mają niezaspokojone pragnienia erotyczne i są frustratkami życiowymi” (Karwatowska, Szpyra-Kozłowska 2005: 83). Ów negatywny charakter określenia stara panna funkcjonuje co najmniej od połowy XVIII wieku, jak podaje W. Kopaliński (1995: 669). Badaczki zauważają również, że owa asymetria dotyczy już wyjściowej pary wyrazów panna - kawaler, ponieważ ten drugi rzeczownik ma również dodatkowe znaczenie: osoby odznaczonej orderem (por. kawaler Orderu Orła Białego, kawaler Orderu Uśmiechu), co powoduje „kolejny paradoks - kobiety odznaczone w tak zaszczytny sposób stają się ...kawalerami”, tym bardziej że słowo kawaler 
panna, przysłowia ${ }^{13}$ : stara panna i z kamieniami na drodze się wadzi; tylko stare panny nie bojq się oblężenia. Niektóre zaś określenia są dwuwyrazowe i mają charakter oficjalny (osoba niezamężna / nieżonata / stanu wolnego). Jak podkreślają dziennikarze, internauci i sami single: bycie singlem jest efektem dokonania samodzielnego wyboru, a starym kawalerem czy stara panną - niekoniecznie z własnej woli - się zostaje. Niektórzy mówią o sobie: jestem sam / sama, ale nie samotny / samotna.

Zapożyczone słowo singiel początkowo funkcjonowało w odmianach środowiskowych polszczyzny ${ }^{14}$, potem w języku mówionym, a współcześnie jest terminem socjologicznym oznaczającym osobę między 25. a 55. rokiem życia, niezależną zawodowo, bez stałego partnera i żyjącą we własnym gospodarstwie domowym (Jaszewska 2006). Niekiedy nadawane jest mu też nieco szersze znaczenie, ponieważ wyraz ten bywa stosowany wobec osób,

buduje także inne wyrażenia nacechowane pozytywnie: słowo kawalerskie i kawalerska fantazja (Karwatowska, Szpyra-Kozłowska 2005: 47). Na marginesie warto zaznaczyć jednak, że kobiety odznaczone orderami bywają też nazywane damami, np. damy Orderu Orła Białego, damy orderu Virtuti Militari, dama orderu Ecce Homo. Warto też dodać, że wyrazy panna i kawaler wychodzą z użycia. Jak ujmuje to M. Łaziński: „Panna jest dziś archaiczną nazwą kobiety niezamężnej (i nierozwiedzionej), używaną systematycznie w kościelnych zapowiedziach przedmałżeńskich, ale bardzo rzadko w dokumentach cywilnych. Panna odpowiada w zapowiedziach przedślubnych nazwie męskiej kawaler, przy czym żadna z tych nazw nie jest używana adresatywnie inaczej niż w żartach" (Łaziński 2006: 245). W tekstach kościelnych zaś, np. w listach pasterskich, dość często pojawiają się wyrazy rzadkie, przestarzałe czy dawne, np. niewiasta.

13 Przysłowia podane w Praktycznym słowniku współczesnej polszczyzny pod red. H. Zgółkowej, t. 27, Poznań 2000. M. Karwatowska i J. Szpyra-Kozłowska podają też inne: Nie pomoże blansz i róż, kiedy panna stara już; stara panna im mniej ma zębów, z tym większym przekasem mówi; stara panna na starego żotnierza czeka; kto się w starej pannie kocha, dwa razy grzeszy i wariant przytoczonego wcześniej - Stara panna i z własnym cieniem się wadzi (Karwatowska, Szpyra-Kozłowska 2005: 83).

14 Bartek Chaciński umieszcza go w Wypasionym słowniku najmłodszej polszczyzny i stwierdza, że „określenie «singel» (z angielskiego - ,pojedynczy”) robi zawrotną karierę już od lat co najmniej dziesięciu" (Chaciński 2003: 78). Jego zdaniem pochodzi „od modnego filmu Singles (Samotnicy, 1992 rok - nie mylić z późniejszym czeskim filmem Samotni) o dwudziestokilkulatkach epoki grunge’u poszukujących miłości albo od telewizyjnego programu „Singled Out” (w Polsce: „Rykowisko”). Singlem jest ten, kto żyje samotnie" (Chaciński 2003: 78). Podaje też przykłady użyć z ogłoszeń towarzyskich, tekstów zamieszczanych na stronach www.republika.pl i www.vegetarian.pl: ,jestem singlem", ,jestem 38-letnim wege-singlem" i ,jestem maxi singlem”. Tworzy też analogiczną formację w zdaniu: „kiedyś byłem mięso-singlem” (Chaciński 2003: 78). 
które żyją bez partnera, choć mają zawarte małżeństwo ${ }^{15}$, lub funkcjonują w nieformalnych związkach ${ }^{16}$. Zwykle jednak podkreśla się, że warunkiem bycia singlem jest brak stałego związku i świadomy wybór takiego modelu życia (por. hasło singiel www.wikipedia.org/wiki).

O zakorzenieniu tego słowa $\mathrm{w}$ polszczyźnie $\mathrm{i}$ istotnej potrzebie nazewniczej, którą ono wypełnia, świadczą liczne publikacje popularnonaukowe ${ }^{17}$ i naukowe ${ }^{18}$ dotyczące singli, zmian modelu rodziny, współczesnego wizerunku osoby samotnej oraz konwersatoria i seminaria podejmujące tę tematykę (w Instytucie Historycznym UW w 2010 roku pt. Współczesne teorie socjologiczne ${ }^{19}$, w Collegium Civitas pt. Singlizm jako nowy styl życia w ponowoczesnym świecie w r. ak. 2010/2011), a także popularność seriali o singlach (Przyjaciele, Ally McBeal, Seks w wielkim mieście). Publikacje prasowe, filmy i kultura popularna upowszechniają wizerunek singla jako osoby niezależnej, wolnej, rozwijającej się zawodowo, odnoszącej sukcesy, korzystającej z życia, zamożnej. Zwykle to mieszkaniec lub mieszkanka dużego miasta, mający/mająca liczne grono przyjaciół i znajomych. Do tych osób kierowane są specjalne oferty wycieczek, wyjazdów, podróży, klubów, spotkań itp.

15 Na przykład osoby żyjące w separacji.

16 Na przykład w pracy U. Rybak (2005).

17 Na przykład: Specyfika XXI w. - single, ,Zwierciadło” 2007, nr 4; Chór solistów coraz więcej Polaków chce żyć w pojedynkę, „Wprost” 1996, nr 36; Użyć życia. 2,5 mln samotnych Polaków, „Wprost” 2001, nr 7; autor: A. Szarlik, www.wprost.pl/archiwum, Single - samotni z wyboru? („Przegląd” $2005 \mathrm{nr} 49$; autor: E. Gietka, www.przegladtygodnik.pl/pl/artykul), Bez drugiej połowy („Przegląd” 2006, nr 40; autor: A. Orlicz, www.przeglad-tygodnik.pl/pl/artykul), Pojedynczo, „Polityka” 2006, nr 42, s. 4-12; autor: K. Lubelska; raport z badań „Wielkomiejski singiel” MB SMG/KRC, badania grupy w wieku 25-35 lat.

18 Na przykład: P. Stein, 2008, Być singlem - próba zrozumienia życia singli, w: P. Sztompka, M. Boguni-Borowska (red.), Socjologia codzienności, Kraków, s. 142-159; Kocik L., 2006, Rodzina w obliczu wartości i wzorów życia ponowoczesnego świata, Kraków; Slany K., 2002, Alternatywne formy życia matżeńsko-rodzinnego w ponowoczesnym świecie, Kraków; Grzeszczyk E., 2005, Pojedyncze profesjonalistki. „, Single professional women” w Polsce i na świecie, „Kultura i Społeczeństwo”, nr 2, s. 199-225; Jabłoński D., Ostasz L., 2001, Zarys wiedzy o rodzinie, małżeństwie, kohabitacji i konkubinacie. Perspektywa antropologii kulturowej i ogólnej, Olsztyn; Żurek A., 2005, Relacje łaczace młodych singli z ich rodzicami, w: W. Wrzesień, A. Żurek, I. Przybył (red.), Rodzice i ich dzieci w tańcu pokoleń, Poznań, s. 71-122; Ruszkiewicz D., 2005, Być singlem, czy też żyć w parze?, „Małżeństwo i Rodzina”, nr 4, s. 12-15.

${ }_{19} \mathrm{~W}$ spisie lektur jest np. wspomniana wyżej praca P. Steina, Być singlem - próba zrozumienia życia singli (por. przypis 18). 
Na zadomowienie tego zapożyczenia wskazuje też utworzenie derywatów słowotwórczych, wspomnianej singielki oraz rzeczowników: $\operatorname{singlizm}^{20}$, singlowanie, singlizacja (singlizacja społeczeństwa) i przymiotników: singlowski (moralność singlowska), singlerski (singlerskie internetowe grupy dyskusyjne) ${ }^{21}$.

W budowaniu pozytywnego obrazu osoby „bez pary” wykorzystuje się więc zapożyczenie pozbawione negatywnych skojarzeń i konotacji. Potrzebę istnienia takiego słowa dobrze uzasadnia też następujący test: proszę w sposób neutralny powiedzieć o kimś bliskim, że żyje w pojedynkę̨, pomimo osiągnięcia wieku stosownego do założenia rodziny. Zastosowanie słowa singiel, singielka pozwala na zbudowanie krótkiej wypowiedzi, nieoceniającej negatywnie tej osoby.

Podobny proces dowartościowania osób poprzez zmianę nazwy widoczny jest w posługiwaniu się wyrazami senior, seniorka i nestor, nestorka, zwłaszcza w liczbie mnogiej (seniorzy, nestorzy). Wykorzystuje się pozytywne skojarzenia związane z niektórymi znaczeniami słowa senior ${ }^{23}$ oraz pozytywnie wartościowane elementy znaczenia słowa nestor ${ }^{24}$, książkowe i/lub podniosłe nacechowanie tych leksemów, zanurzenie w kulturze i łączliwość, zwłaszcza nobliwość niektórych połączeń: senior rodu, rodziny, senior polskich literatów, nestor nauki polskiej (podobnie seniorka i nestorka). Funkcjonujące nazewnictwo: ludzie w wieku poprodukcyjnym, emeryci, ludzie starsi, starzy ludzie, starcy, ludzie w podeszłym wieku, osoby po sześćdziesiatce (czasami również: pięćdziesiatce) albo oferuje wielowyrazowe określenia oficjalne lub potoczne, albo słowa z rdzeniem star- (w tym eufemizm ludzie starsi), przy-

${ }^{20}$ Na stronach Collegium Civitas: www.civitas.edu.pl [data dostępu: 25.05.2011].

${ }^{21}$ Z artykułu D. Janiszewskiej, 2006, Single, „W Drodze”, nr 3 (391) [www. mateusz. pl, data dostępu: 25.05.2011] i tekstu Wyższa Szkoła Przytulania, „Rzeczpospolita”, rubryka „Plus Minus”, 8.10.2005 [http://archiwum.rp.pl] oraz publikacji zamieszczonych na stronie www.katolik.pl [data dostępu: 10.06.2011 (K. Zalewska)].

$22 \mathrm{Z}$ pominięciem sióstr i braci zakonnych oraz księży.

23 Senior 1. ksiażk. a) 'najstarszy wiekiem członek rodziny, rodu (ojciec, brat)', b) 'najstarszy wiekiem lub latami pracy członek jakiegoś zespołu, jakiejś społeczności', 3. hist. a) 'w Polsce dzielnicowej: najstarszy z Piastów, któremu podlegali książęta poszczególnych dzielnic', b) 'w prawie feudalnym: feudał sprawujący opiekę nad zależnym od niego wasalem' (wg USJP).

24 Według USJP: nestor 1. ksiażk. a podn. 'najstarszy, najbardziej doświadczony, zasłużony przedstawiciel jakiejś grupy, zbiorowości, otoczony powszechnym szacunkiem’; Nestor to także imię mitycznego króla, najstarszego i najbardziej doświadczonego wodza greckiego spod Troi, bohatera Iliady. 
wołujące starość, która współcześnie nie jest postrzegana jako wartość. Żyjemy wszak w świecie kultu młodości, szybkości, sprawności fizycznej i dążenia do zewnętrznego piękna. Słowo emeryt nie wskazuje zaś na pełnienie jakieś pozytywnej roli w społeczeństwie, a w kontekście ostatnich dyskusji o zmianach w systemie emerytalnym wręcz straszy. Czytamy i słyszymy więc o klubach seniora, akademiach dla seniora (np. Nowohucka Akademia Seniora), dniach seniora ${ }^{25}$, portalu seniorów (StarszakiPlus.pl), forach i stronach dla seniorów (forum50+seniorzy XXI wieku, byćSeniorem.pl), stowarzyszeniach seniorów, problemach seniorów, widzimy dodatki do gazet zatytułowane „Senior” (z gazety: www.dziennik.krakow.pl/magazyny/senior), oglądamy reklamy kredytów dla nestorów (Bank Pocztowy), istnieją pocztowe konta Nestor (notabene dla seniorów - por. www.pocztowy.pl). Rynek oferuje produkty, usługi i towary przeznaczone dla tej grupy wiekowej: programy edukacyjne dla seniorów, wakacje dla seniorów, porady dla seniorów, ksztatcenie seniorów. Powstają również książki i artykuły o polityce państwa wobec seniorów, sposobach spędzania czasu wolnego i aktywności seniorów, omawiające ich potrzeby, w których stosuje się omawiane słowo, np. Encyklopedia seniora (Borsowa i in. 1986), Seniorzy w rodzinie, instytucji i społeczeństwie (Fabiś 2005), Polski senior a społeczeństwo informacyjne (Tomczyk 2008), Seniorzy w sieci (Teodorczyk) ${ }^{26}$. Na proces neosemantyzacji wpływa też znaczenie angielskiego słowa senior.

Zmiany sposobu myślenia o świecie i relacjach pomiędzy człowiekiem a zwierzętami widoczne są również w nowej łączliwości leksykalnej wyrazu adopcja. Oprócz typowych połączeń: adopcja dziecka, dokonać adopcji,

25 W dwóch znaczeniach: 1) uroczystości ku czci najstarszych mieszkańców miejscowości, 2) obniżka cen dla osób starszych w dany dzień tygodnia (np. w sklepach, zakładach fryzjerskich).

${ }^{26}$ Bardzo liczne są podręczniki korzystania z komputerów i Internetu, przeznaczone dla seniorów [por. Krawczyński E., 2008, Komputer PC dla seniorów, Gliwice; Krzymowski B., 2007, Komputer - notebook (laptop) - netbook. Poradnik dla seniorów młodych, Warszawa; Krzymowski B., 2009, Komputer dla seniora: dla nieinformatyków, Warszawa; Muir N. C., 2009, Komputer dla seniorów. Informatyka dla bystrzaków, Gliwice; Price M., Price S., 2008, Internet dla seniorów, Katowice; Price S., 2008, Komputer dla seniorów, Katowice; Born G., 2007, Internet. Łatwy start dla seniorów, Poznań; Born G., 2007, Komputer. Łatwy start dla seniorów, Poznań; Born G., 2007, Notebook. Latwy start dla seniorów, Poznań; Gajewski P., 2010, Komputer dla seniora: kurs od podstaw: jak korzystać z komputera i Internetu, Warszawa; Jaronicki A., 2010, Komputer dla seniorów, Warszawa]. 
związanych ze słownikowym znaczeniem ${ }^{27}$ tego rzeczownika, spotykamy się od wielu lat z wyrażeniami: adopcja zwierząt, adopcja psa, kota, które są stosowane zamiast przygarnięcie, wzięcie (psa, kota, zwierzęcia), zaopiekowanie się (psem, kotem, zwierzęciem). W schroniskach dla zwierząt często należy wypełniać specjalne druki adopcji. Można powiedzieć, że widoczny jest tu proces personalizacji zwierząt, które stają się (lub są) członkami rodziny. W tych połączeniach widać też semantyczne nawiązanie do drugiego ze znaczeń czasownika adoptować, które ma charakter przenośny i książkowy 'zaopiekować się, opiekować się kimś' (USJP).

Jednak coraz częściej spotykamy się z innymi połączeniami: adopcja na odległość, adopcja modlitewna, adopcja serca, adopcja duchowna, duchowa, adopcja rzeczy czy obiektu, por.:

1) adopcja na odległość:

- Adopcja na odległość (www.adopcja.salezjanie.pl, dostęp: 19.10.2011)

- Celem istnienia strony adopcjanaodleglosc.pl jest propagowanie idei pomocy kenijskim dzieciom zagrożonych głodem i analfabetyzmem (adopcjanaodleglosc.pl, dostęp: 19.10.2011);

- Projektem Adopcji na Odległość objęte sq [...] dziewczynki z Rehabilitacyjnego Domu Dziecka prowadzonego przez franciszkanów w miasteczku Limuru [...] (www.misje.gdansk.franciszkanie.pl/adopcja1.html, dostęp: 19.10.2011);

- Adopcja na odległość Ruchu Światto-Życie (oaza-adopcjanaodleglosc.blogspot.com, dostęp: 19.10.2011);

- Zapraszamy na strony Adopcji na odległość, projektu Caritas Polska (www.adopcjanaodleglosc.caritas.pl, dostęp: 19.10.2011);

- Adopcja Serca (Adopcja na odległość, Adopcja Miłości) - forma pomocy ubogim dzieciom (najczęściej z krajów Trzeciego Świata), która sluży tworzeniu partnerstwa między nimi a ofiarodawcami (rodzinami, osobami indywidualnymi, czy grupami osób takimi jak grupa parafialna, czy klasa szkolna) (pl.wikipedia.org/wiki/Adopcja_serca ${ }^{28}$, dostęp: 19.10.2011);

27 Ze znaczeniem oznaczonym literą $a$ w USJP: praw. a) 'akt prawny polegający na uznaniu cudzego dziecka za własne, przysposobienie', b) 'przyjęcie przez władze prawodawczą obcego prawa za obowiązujące prawo krajowe'.

${ }^{28}$ W Wikipedii podane są też informacje dodatkowe dotyczące takiej formy adopcji: „Darczyńcy - osoby fizyczne bądź firmy - deklarują się, podpisując umowę o przy- 
- Jan Pawet II, Evangelium Vitae: „Szczególnie wymownym znakiem solidarności między rodzinami jest adopcja. Wśród różnych form adopcji warto zalecić także adopcje na odlegtość. Ten typ adopcji nie taczy się z koniecznościq wyrwania dzieci z naturalnego środowiska" (pl.wikipedia.org/wiki/Adopcja_serca, dostęp: 19.10.2011);

2) adopcja modlitewna:

W zwiqzku z inauguracja w dniu 19 czerwca Roku Kapłańskiego ruch „Lazo de Amor Mariano” [...] ruszyt z kampaniq ,,Modlitewnej Adopcji Kapłanów”. Uczestnicy kampanii zobowiqzuja się do codziennej modlitwy $w$ intencji jednego kapłana celem ,wyproszenia łask potrzebnych kapłanom do petnienia ich misji w świecie naznaczonym pokusami i niebezpieczeństwami" (www.papaboyspolska.wordpress.com/2009/06/30, por. też www.sekretariat_misyjny.pl/index, dostęp: 18.05.2011);

3) adopcja serca:

- Adopcja Serca to pomoc konkretnemu dziecku żyjacemu w Afryce, które jest sierota lub którego rodzice sq $w$ bardzo trudnej sytuacji finansowej (www.klig.czest.pl/martin/adopcja.html);

- program Adopcja serca (www.gim2b.waw.ids.pl, dostęp: 18.05.2011);

4) adopcja duchowna a. duchowa (również duchowa adopcja):

- Duchowa Adopcja Dziecka Poczętego jest szczególna forma właczenia się w obronę życia. Polega na modlitewnym przyjęciu pod opieke jednego dziecka poczętego (www.misjonarze-wroclaw.pl, dostęp: 18.05.2011);

jęciu pod opiekę dziecka lub dzieci. Opieka ma formę comiesięcznych opłat (zwykle 15-20 dolarów) na wyżywienie, odzież, kształcenie, ochronę zdrowia i inne potrzeby dzieci. Najczęściej są to sieroty, wychowywane przez dalszą rodzinę lub ludzi obcych (nierzadko wdowy), którzy jednak - sami mając kilkoro dzieci - bez pomocy finansowej z Europy lub Ameryki nie byliby w stanie zapewnić im wykształcenia. Adopcja Serca obejmuje też dzieci pokrzywdzone przez los, które w inny sposób nie mogłyby otrzymać wykształcenia, np. dzieci osób dotkniętych trądem, ofiary Tsunami. [...] W Polsce tą formą pomocy zajmują się ruchy katolickie (Ruch Solidarności z Ubogimi Trzeciego Świata MAITRI) w tym (Stowarzyszenie Wymiany i Pojednania), zakony (księża pallotyni, salezjanie, siostry karmelitanki), instytuty świeckie (Sekretariat Misyjny Jeevodaya należący do Instytutu Prymasa Wyszyńskiego, organizacje kościelne Caritas), stowarzyszenia (Salezjański Wolontariat Misyjny „Młodzi Światu”). Wspierają one dzieci m.in. z Rwandy, Burundi, Demokratycznej Republiki Konga, Kamerunu, Sudanu, Boliwii, Indii, Sri Lanki, Indonezji, Tajlandii, Tanzanii.” (pl.wikipedia.org/wiki/Adopcja serca, dostęp: 19.10.2011). 
- IDEA DUCHOWEJ ADOPCJI wzywa do podjęcia modlitewnego wołania $w$ intencji ocalenia zagrożonego życia $w$ tonie matki $i$ duchowego towarzyszenia narodzonemu już dziecku [...]. HISTORIA DUCHOWEJ ADOPCJI w Archidiecezji Poznańskiej jest kontynuacja dzieła, które w Polsce rozpoczyna się w roku 1987 wraz z pierwszymi osobami, które podejmuja ja w Warszawie. Od 1998 r., kiedy w Poznaniu w dzień Zwiastowania NMP podjęło Duchowa Adopcje 120 osób (www.dr.archpoznan.pl, dostęp: 18.05.2011);

- Dzieło Duchowej Adopcji Sióstr Zakonnych powstało jako swoista odpowiedź na Apostolat Margaretka i Dzieło Duchowej Adopcji Kapłanów. Jak można się domyślić sq to modlitwy za księży. Jednak siostry zakonne, których głównym zadaniem jest modlitwa same bardzo jej potrzebuja (http://ddasz.wordpress.com, dostęp: 18.05.2011);

- Dzieło Duchowej Adopcji Kobiet (www.po-moc/duchowo-i-modlitewnie.html, dostęp: 18.05.2011);

5) adopcja rzeczy a. obiektu:

Proponujemy Państwu udziat $w$ programie ADOPCJA OBIEKTU. Program skierowany jest zarówno do indywidualnych zwiedzajacych jak i firm i obejmuje różne typy obiektów. Wystarczy tylko określić wysokość dobrowolnej donacji na rzecz wybranego obiektu znajdujacego się na ekspozycji, w magazynie lub w konserwacji. Państwa donacja pomoże w utrzymaniu i konserwacji jednego z tysięcy niezwykle cennych eksponatów. Po wpłaceniu kwoty w pewnej wysokości na rachunek PME obiekt zostanie oznaczony jako adoptowany - znajdujacy się pod opiekq osoby/firmy (przy obiekcie na ekspozycji znajdzie się specjalna plakietka $z$ informacja o treści uzgodnionej z donatorem) (Państwowe Muzeum Etnograficzne w Warszawie, www.sztuka.pl, dostęp: 24.05.2011).

W znaczeniach tych wyrażeń pojawiają się nowe elementy semantyczne: zaopiekowanie polega na udzieleniu pomocy finansowej (sierotom i biednym dzieciom w krajach Trzeciego Świata, ogrodom zoologicznym - na wyżywienie zwierząt oraz muzeom w celu pokrycia kosztów konserwacji i utrzymania eksponatów) albo na modlitwie w intencji (nienarodzonego dziecka, siostry zakonnej, kapłana). Przywołane przykłady wskazują na znaczne rozszerzenie znaczenia omawianego wyrazu. 
Jeżeli przyjmiemy za Ryszardem Tokarskim, że słowa i ich znaczenia są ,swoistymi interpretacjami rzeczywistości”, subiektywnymi z założenia i umożliwiającymi „wielość możliwych spojrzeń na otaczający świat” (Tokarski 2001: 345), to można powiedzieć, że w opisywanych neologizmach słowotwórczych, zapożyczeniach i neosemantyzmach spotykamy się z innymi propozycjami interpretacji świata. Zmienia się nasz sposób myślenia o osobach „,bez pary”, zwierzętach, osobach starszych, starzeje się nasze społeczeństwo, ewoluują modele życia, próbujemy więc na nowo opisać świat. Przekształcamy zatem leksykę tak, aby odpowiadała psychicznym i kulturowym potrzebom współczesnego człowieka (Tokarski 2001: 352).

Omówione innowacje powstały $\mathrm{z}$ chęci zastąpienia istniejących nazw i w ten sposób wpłynięcia na postrzeganie odpowiadających im desygnatów. Umożliwiają inny opis rzeczywistości, związany z odmiennymi konotacjami pragmatycznymi czy dystansowaniem się od zastanych wzorców kultury. Rzecz, zjawisko pozostaje bez zmiany, ale ich nazwa koncentruje się na pożądanych w oczach nadawcy cechach, które są wskazane albo w temacie słowotwórczym (spopielić), albo w skojarzeniach związanych z podstawowym znaczeniem słowa (adopcja, senior) lub typową łączliwością (senior rodu).

I choć niektóre przykłady można uznać za współczesne eufemizmy, ponieważ za ich pomocą omija się tabu, związane z zakazem używania słów przykrych, niepoprawnych lub niepożądanych, to jednak równie ważna jest ich funkcja perswazyjna: wpływanie na ocenę opisywanych rzeczy i zjawisk oraz na zmianę postaw ludzi (walka nazwami widoczna jest zwłaszcza w dyskusjach o spalarniach - krematoriach, byciu osobą ,bez pary”: osoba samotna, stary kawaler, stara panna czy singiel, singielka).

Celem ich powstania było nie tyle stworzenie możliwości wyboru (zaistnienie alternatywy), ile świadome zastąpienie istniejących wyrazów czy połączeń, tak jak wyrażenie osoba niepetnosprawna zastąpiło dziś w wielu kontekstach wyrazy kaleka, inwalida. 


\section{Bibliografia}

Borsowa I., Pędich W., Piotrowski J., Różniatowski T., Rudnicki S. (red.), 1986, Encyklopedia seniora, Warszawa: Wiedza Powszechna.

BurKaCKa I., 2010, O sufiksach -ni(a) i -eri(a) w funkcji wykładników nazw miejsc, LingVaria, nr 1(9), s. 31-38.

Chaciński B., 2003, Wypasiony stownik najmłodszej polszczyzny, Kraków: Wydawnictwo Znak.

DĄBRowsKa A., 1993, Eufemizmy wspótczesnego języka polskiego, Wrocław: Wydawnictwo Uniwersytetu Wrocławskiego.

ENGELKING A., 1984, Istota i ewolucja eufemizmów (na przykładzie zastępczych określeń śmierci), Przeglad Humanistyczny 4, s. 115-129.

FABIŚ A. (red.), 2005, Seniorzy w rodzinie, instytucji i spoleczeństwie. Wybrane zagadnienia wspótczesnej gerontologii, Sosnowiec: wydawnictwo Humanitas.

Grabias S., 1981, O ekspresywności języka. Ekspresja a stowotwórstwo, Lublin: Wydawnictwo Lubelskie.

JASIK A., 2009, Tabuizowanie tematu śmierci i realiów z nią związanych w różnych kręgach środowiskowych Opolszczyzny, w: A. Dąbrowska (red.), Język a kultura, t. 21, Tabu w języku i kulturze, Wrocław: Wydawnictwo Uniwersytetu Wrocławskiego, s. 175-194.

JASZEwSKa D., 2006, Single, W Drodze, nr 3 (391), www.mateusz.pl [dostęp 5.05.2011].

Karwatowska M., Szpyra-KozŁowska J., 2005, Lingwistyka ptci: ona i on w języku polskim, Lublin: Wydawnictwo UMCS.

Kopalí́ski W., 1995, Encyklopedia ,drugiej ptci”, Warszawa: Wydawnictwo Bellona.

ŁazıŃski M., 2006, O panach i paniach. Polskie rzeczowniki tytularne i ich asymetria rodzajowo-ptciowa, Warszawa: Wydawnictwo Naukowe PWN.

Markowski A., 2005, Kultura języka polskiego. Teoria. Zagadnienia leksykalne, Warszawa: Wydawnictwo Naukowe PWN.

PSWP = ZGóŁKOWA H. (red.), 1994-2005, Praktyczny słownik wspótczesnej polszczyzny, Poznań: Wydawnictwo Kurpisz.

Ryвak U., 2005, Bycie „singlem” w Polsce, w: S. Mocek (red.), Polacy XXI wieku. Nowe style życia, Zeszyty Naukowe Collegium Civitas, Warszawa.

Teodorczyk A., Seniorzy w sieci, PBI/Gemius, http://blog.gemius.pl.

ToKARski R., 2001, Słownictwo jako interpretacja świata, w: J. Bartmiński (red.), Współczesny język polski, Lublin: Wydawnictwo UMCS, s. 343-370.

Tомсzyк Ł., 2008, Polski senior a społeczeństwo informacyjne, Poradnik Bibliotekarza, nr 1, s. 14-15. 
USJP = DuBISZ S. (red.), 2003, Uniwersalny stownik języka polskiego, Warszawa: Wydawnictwo Naukowe PWN.

Waszakowa K., 2007, Wariantywne postaci neologizmów w świetle adaptacyjnej funkcji słowotwórstwa, Prace Filologiczne LIII, s. 691-699.

Waszakowa K., 2009, Derywacja słowotwórcza a semantyczna, w: V. Rадева, Ц. Аврамоva, Ю. Балтоva (red.), Словообразувание и лексикология. Балгарска академия на науките, София: Wydawnictwo Uniwerysteckie „Sv. Kliment Ochrydzki", s. 209-219.

WidŁak S., 1963, Tabu i eufemizm w językach nowożytnych, Biuletyn PTJ XXII, s. $93-102$.

\section{Why spopielarnia ('incinerator') and not krematorium ('crematory')? Another View of Alternative Innovations}

\section{( s u m mary)}

The article presents considerations on the function and nature of alternative innovations. They allow different description of reality, associated with different pragmatic connotations of words or with distancing from the already existing cultural patterns. The new name focuses on the characteristics desired by language users that are indicated either in the word-formation basis (e.g. spopielic' 'to incinerate'), or in the associations related to the primary meaning of the word (e.g. adopcja 'adoption', senior 'senior') or the typical connectivity (e.g. senior rodu 'family senior').

Some examples can be considered contemporary euphemisms, because they help avoid the taboos associated with the prohibition of using unpleasant, incorrect or undesirable words. Their persuasive function is though equally important: influencing the assessment of things and phenomena described and the change of people's attitudes (the fight using names is particularly evident in discussions about spalarnia 'incinerator' and krematorium 'crematory', or about being a person with no partner: osoba samotna 'lonely person', stary kawaler 'confirmed bachelor', stara panna 'old maid', singiel, singielka 'single person').

Such forms were created not only to give a choice (existence of alternative), but most of all to intentionally replace the existing words or connections, e.g. in many contexts, the expression osoba niepetnosprawna 'disabled person' has replaced the words kaleka or inwalida 'crippled person'. 